\title{
Mitogenic stimulation of resting $T$ cells causes rapid phosphorylation of the transcription factor LSF and increased DNA-binding activity
}

\author{
Janet L. Volker, ${ }^{1,2}$ Lucia E. Rameh, ${ }^{1,3}$ Quan Zhu, ${ }^{1,4}$ James DeCaprio, ${ }^{1}$ and Ulla Hansen ${ }^{1,2,5}$ \\ Dana-Farber Cancer Institute, ${ }^{1}$ and Department of Microbiology and Molecular Genetics, ${ }^{2}$ Harvard Medical School, Boston, \\ Massachusetts 02115 USA
}

The mammalian transcription factor LSF (CP2/LBP-1c) binds cellular promoters modulated by cell growth signals. We demonstrate here that LSF-DNA-binding activity is strikingly regulated by induction of cell growth in human peripheral $\mathrm{T}$ lymphocytes. Within $15 \mathrm{~min}$ of mitogenic stimulation of these cells, the level of LSF-DNA-binding activity increased by a factor of five. The level of LSF protein in the nucleus remained constant throughout this interval. However, a rapid decrease in the electrophoretic mobility of LSF, attributable to phosphorylation, correlated with the increase in DNA-binding activity. pp44 (ERK1) phosphorylated LSF in vitro on the same residue that was phosphorylated in vivo, specifically at amino acid position 291, as indicated by mutant analysis. As direct verification of the causal relationship between phosphorylation and DNA-binding activity, treatment in vitro of LSF with phosphatase both increased the electrophoretic mobility of the protein and decreased LSF-DNA-binding activity. This modulation of LSF-DNA-binding activity as T cells progress from a resting to a replicating state reveals that LSF activity is regulated during cell growth and suggests that LSF regulates growth-responsive promoters.

[Key Words: LSF; MAP kinase; mitogens; phosphorylation; DNA-binding; T lymphocytes]

Received February 21, 1997; revised version accepted April 17, 1997

To obtain proper progression into the cell cycle, growth stimulation of resting cells requires precisely regulated patterns of transcription. Primary human peripheral $\mathrm{T}$ cells represent a particularly useful model system for cell growth regulation. These cells, when isolated, are in $G_{0}$ and only enter the cell cycle when presented with antigen or mitogens. On antigen stimulation of $\mathrm{T}$ cells in vivo, a specific set of ordered events occurs within minutes to up to 10 days, eventually leading to cell division and immunologic function (Crabtree 1989; Rao 1991). This biological progression can be mimicked in vitro by stimulating cells with phorbol esters, ionophores, lectins, or antibodies to the T-cell receptor. Stimulation of $\mathrm{T}$ cells either with antigen or chemical mitogens results in expression of c-fos and c-myc within 15 and 30 min, respectively (Granelli-Piperno et al. 1986; Reed et al. 1986, 1987; Crabtree 1989|. Following expression of these immediate early/early genes, the $\mathrm{T}$ cells express IL-2 and IL-2 receptor at $2 \mathrm{hr}$, replicate DNA at $\sim 16-20$

Present addresses: ${ }^{3}$ Center for Blood Research, Harvard Medical School, Boston, Massachusetts 02115 USA; ${ }^{4}$ Intraimmune Therapies Inc., Boston, Massachusetts 02115 USA.

${ }^{5}$ Corresponding author.

E-MAIL ulla hansen@dfci.harvard.edu; FAX (617) 375-8221. hr, and finally divide at $24-48 \mathrm{hr}$ post-stimulation /Crabtree 1989 |.

Signal transduction cascades induced by mitogenic stimuli directly drive the modification of preexisting pools of cellular proteins, including transcription factors (Hunter and Karin 1992; Montminy 1993). These mitogen-induced post-translational modifications, often phosphorylation events, subsequently regulate cellgrowth-dependent transcription. In particular, extracellular response kinases (ERK), a subfamily of the mitogenactivated protein kinases (MAP kinases), have been shown to phosphorylate a variety of transcription factors that have been implicated in controlling the expression of genes essential for cell proliferation (Davis 1993; Hill and Treisman 1995; Hunter 1995; Vojtek and Cooper 1995). These factors include c-Jun (Pulverer et al. 1991), Elk-1 (Gille et al. 1992; Marais et al. 1993), and STATs (Boulton et al. 1995; David et al. 1995; Wen et al. 1995). All of these factors are involved in activating early response genes.

In general, phosphorylation has been shown to modulate multiple functions of transcription factors: DNAbinding activity, nuclear localization /Ghosh and Baltimore 1990; Moll et al. 1991; Fu 1992; Fu and Zhang 1993; Shuai et al. 1993), protein:protein interactions (Chel- 
lappan et al. 1991; Shirodkar et al. 1992), and transactivation activity (Pulverer et al. 1991; Marais et al. 1993; for review, see Hunter and Karin 1992). When DNAbinding activity is targeted, the affinity of the protein/ DNA interaction is generally decreased by phosphorylation, as in Oct-1 (Roberts et al. 1991; Segil et al. 1991) and c-Jun (Lin et al. 1992). For a small number of transcription factors, however, phosphorylation can increase the specific affinity of the factor for its recognition sequence in DNA. This group of proteins includes serum response factor (SRF), when phosphorylated at a ribosomal protein S6 kinase (RSK)-dependent site (Rivera et al. 1993), the plant transcription factor GBF1 (Klimczak et al. 1992), and ATF-2 (Abdel-Hafiz et al. 1992). Finally, phosphorylation can alter the rate of binding of a protein to DNA, but not the overall affinity (e.g., phosphorylation of SRF by casein kinase II; Janknecht et al. 1992; Marais et al. 1992).

The mammalian transcription factor LSF was identified initially as a $63-\mathrm{kD}$ protein that specifically binds to and stimulates transcription from the simian virus 40 (SV40) major late promoter (Huang et al. 1990). Analysis of the LSF clone indicates that it is identical to the human $\alpha$-globin transcription factor CP2 (Lim et al. 1992) and to LBP-1c/UBP-1, which binds multiple sites within the human immunodeficiency virus (HIV) long terminal repeat (LTR) (Jones et al. 1988; Wu et al. 1988; Malim et al. 1989; Kato et al. 1991; Yoon et al. 1994). LSF also binds with high affinity to sites within the c-fos promoter immediately downstream of the serum response element (SRE) (R. Misra, H.-C. Huang, M. Greenberg, and $U$. Hansen, unpubl.) and within the ornithine decarboxylase (ODC) promoter (J. Volker, A.P. Butler, and U. Hansen, unpubl.) in a region responsive to mitogens (Mar et al. 1995). Because of the well-characterized regulation of the c-fos promoter at the $\mathrm{G}_{0} / \mathrm{G}_{1}$ boundary, including in human peripheral $\mathrm{T}$ cells (Greenberg and Ziff 1984; Granelli-Piperno et al. 1986; Crabtree 1989), the mitogenic induction of ODC transcription /Kahana and Nathans 1984; Feinstein et al. 1985; Greenberg et al. 1985; Olson and Spizz 1986; Katz and Kahana 1987; Abrahamsen and Morris 1990) and the coupling of SV40 late gene expression to cell growth, we have investigated whether LSF-DNA-binding activity is cell growth-regulated. We present evidence that LSF is rapidly phosphorylated on mitogenic stimulation of resting T cells, that MAP kinase, specifically pp44 (ERK1), phosphorylates LSF in vitro on the same serine residue that is phosphorylated in vivo, and that the DNA-binding activity of LSF is enhanced by phosphorylation.

\section{Results}

Regulation of LSF-DNA-binding activity during the $G_{0} / G_{1}$ transition

To investigate the biological regulation of LSF, immunological reagents were developed. Rabbit polyclonal anitsera were raised against two peptides /Shirra et al. 1994). As proof that these antisera were directed against the defined LSF-DNA-binding activity, immunoaffinity purified antibodies ( $\alpha$-pepLSF) were assayed in a gel mobility-shift experiment for their ability to interact with the LSF-DNA complex. $\alpha$-pepLSF1-1 completely supershifted the LSF-DNA complex formed from HeLa nuclear extract (Fig. 1A, lanes 1,2). We note that the level of antibody-LSF-DNA complex was elevated as compared with that of the nonsupershifted species, presumably attributable to stabilization of the LSF-DNA interaction by this antibody. In contrast, $\alpha$-pepLSF2- 1 neither supershifted nor disrupted the LSF-DNA complex (Fig. 1A, lane 3), although it did react against denatured, purified LSF by Western blot analysis (data not shown). In addition to the $\alpha$-pepLSF1- 1 antiserum, two other LSF antipeptide antisera directed against either peptide $1(\alpha-$ pepLSF 1-2) or peptide 2 ( $\alpha$-pepLSF2-2) completely supershifted the HeLa cell LSF-DNA complexes (data not shown). Therefore, all detectable proteins that interact specifically with LSF-binding sites in these HeLa extracts contain the product of the identified LSF (CP2/ LBP-1c) gene. Similar data were obtained for crude

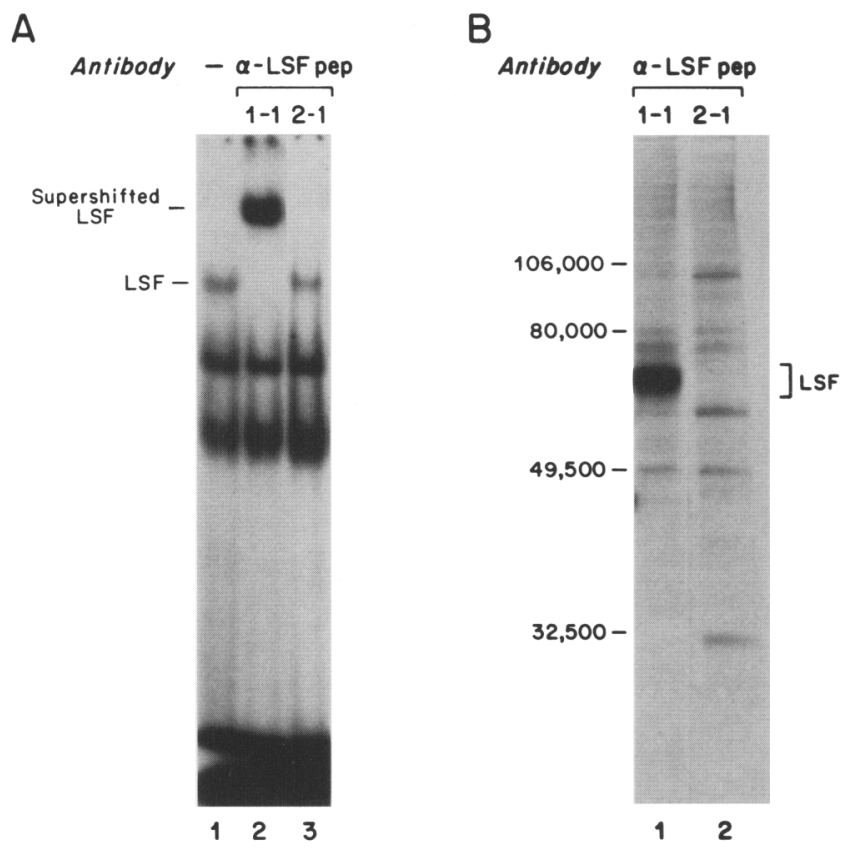

Figure 1. LSF antipeptide antibody characterization. $(A) \mathrm{Gel}$ mobility-shift analysis of LSF-DNA-antibody ternary complexes from HeLa cell nuclear extract. DNA-binding reactions contained HeLa cell nuclear extract, LSF-280 DNA (Huang et al. 1990), and either no antibody (lane 1), $\alpha$-pepLSF1-1 (lane 2), or $\alpha$-pepLSF2-1 (lane 3). Positions of LSF-DNA and supershifted LSF-DNA (LSF-DNA-antibody) complexes are indicated. Free DNA is shown at the bottom of the gel. The remaining two bands reflect nonspecific binding to DNA, as shown by competition analyses (data not shown). (B) Immunoprecipitation analysis of radio-labeled LSF from HeLa cells. HeLa cells were labeled with $\left[{ }^{35} \mathrm{~S}\right]$ methionine as described in Materials and Methods, and extracts immunoprecipitated with either $\alpha$-pepLSF1-1 (lane 1) or $\alpha$-pepLSF2-1 (lane 2). Samples were separated by SDS-PAGE and an autoradiograph of the gel developed. The positions of molecular weight markers and the broad position of the LSF bands are indicated. 
nuclear extracts from human peripheral T cells and Balb/ c-3T3 (clone A31) mouse fibroblasts (data not shown). The specificity of the $\alpha$-pepLSFl- 1 antiserum for LSF was addressed by immunoprecipitation analysis (Fig. 1B). $\alpha$-pepLSF2-1 antiserum was used as a negative control, because of its inability to recognize native LSF. $\alpha$-pepLSF1-1 (Fig. 1B, lane 1) immunoprecipitated a group of bands from HeLa nuclear extract labeled with $\left[{ }^{35} \mathrm{~S}\right]$ methionine migrating at approximately the mobility expected for LSF, which were not immunoprecipitated by $\alpha$-pepLSF2-1 (Fig. 1B, lane 2). As shown below (Fig. 3A), these multiple bands represent differentially phosphorylated forms of the same LSF gene product.

Based both on the presence of LSF-DNA-binding sites within the human c-fos promoter and the human ODC promoter, and on the rapid induction of expression from these promoters as cells exit $\mathrm{G}_{0}$ (see Introduction), we monitored LSF-DNA-binding activity on progression of resting $\mathrm{T}$ cells into the cell cycle. LSF-DNA-binding activities within nuclear extracts from unstimulated $\mathrm{G}_{0}$ cells and from early $G_{1}$ cells at varying times following mitogen treatment were compared by a gel mobilityshift assay (Fig. 2A). The high affinity LSF-280 site within the SV40 late promoter (Huang et al. 1990), which is nearly identical to the LSF-DNA-binding site within the $\mathrm{c}$-fos promoter, was used for these assays. Extremely low levels of LSF-DNA-binding activity were detected in unstimulated peripheral $\mathrm{T}$ cells (Fig. 2A, inset, lane 1 ). However, LSF-DNA-binding activity increased rapidly to an average of 4.5 -fold above the $G_{0}$ level within 15 min of mitogenic stimulation (Fig. 2A). The level of LSFDNA-binding activity remained fivefold higher than the level in resting cells for at least $3 \mathrm{hr}$.

To determine whether these striking alterations in DNA-binding activity were attributable to changes in the levels or the modification of the LSF protein within the nucleus, these nuclear extracts were examined by Western blot analysis (Fig. 2B). The resulting data indicated, first, that the level of LSF protein in the nucleus was unchanged as $\mathrm{T}$ cells progressed into the cell cycle (Fig. 2B, cf. lane 2 with lanes 3-5). Second, extracts containing higher levels of LSF-DNA-binding activity contained only a slower migrating form of the LSF protein (Fig. 2B, lanes 3-5). Finally, and most strikingly, a quantitative shift in the mobility of LSF was observable within 5 min of mitogenic stimulation (Fig. 2B, lane 3), suggesting that the protein is modified rapidly. Serum stimulation of quiescent NIH $3 \mathrm{~T} 3$ fibroblasts also resulted in a quantitative shift in the mobility of LSF within 5 min of serum addition (data not shown). Consistent with the modification of a preexisting pool of LSF, the shift in mobility of the protein after mitogenic stimulation was also observed in the presence of the protein translation inhibitor cycloheximide (data not shown). Similar data were obtained whether or not additional steps were taken to remove contaminating B cells, neutrophils, macrophages, or previously activated $T$ cells from the population of cells before analysis (data not shown). Therefore, the rapid increase in LSF-DNAbinding activity occurs following mitogenic stimulation
A
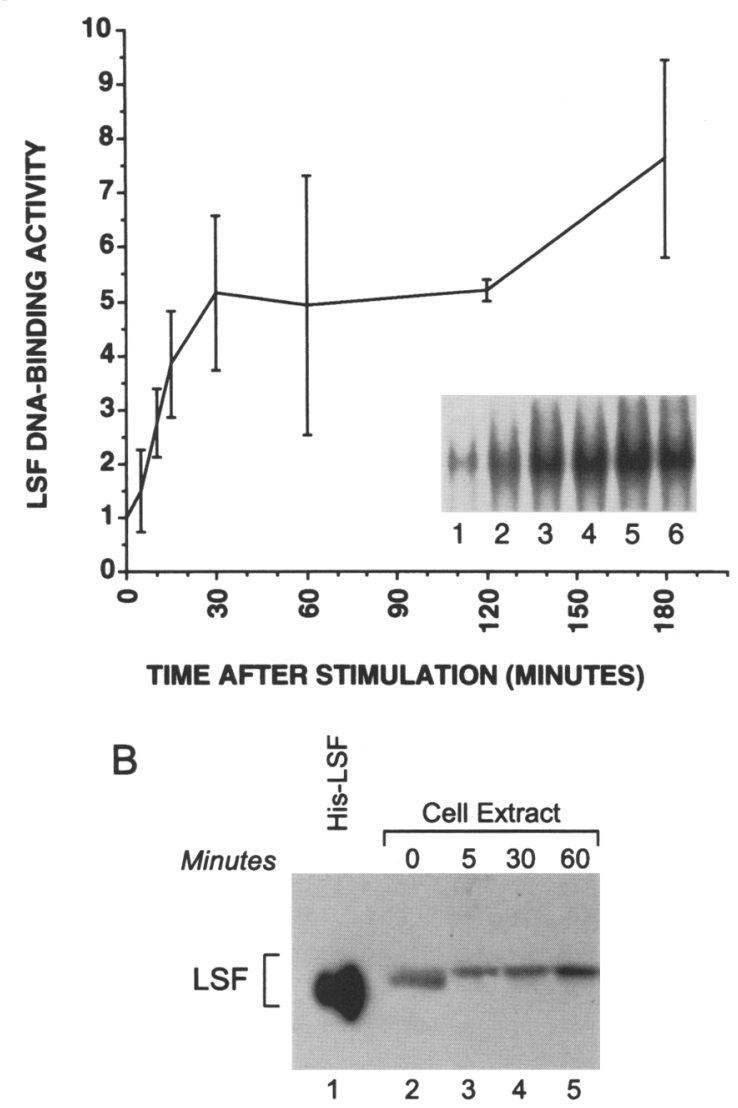

Figure 2. Mitogenic stimulation of human peripheral $\mathrm{T}$ cells rapidly increases the DNA-binding activity of LSF and decreases the electrophoretic mobility of LSF. (A) Quiescent T cells were stimulated with PMA, PHA, and ionomycin. Nuclear extracts were prepared from unstimulated cells and from cells stimulated for increasing periods of time and were analyzed by a gel mobility-shift assay as described in Materials and Methods. The levels of LSF-DNA complexes were quantitated by analysis on a PhosphorImager (Molecular Dynamics) using ImageQuant software. Levels of DNA/LSF complexes in the various samples |normalized to the total amount of radioactive DNA in each lanel were then normalized to the level of LSF/DNA complexes in the $G_{0}$ extract. The data points represent a compilation of five separate experiments, with different batches of peripheral $\mathrm{T}$ cells being stimulated in each case. Standard deviations are indicated. Inset panel is a representative gel shift experiment. Times following stimulation are as follows: lanes 1-6: 0, 5, 10, 15,30 , and $60 \mathrm{~min}$, respectively. $(B) \mathrm{T}$ cells were stimulated and nuclear extracts were prepared as described in Materials and Methods. Fifty micrograms of extract was loaded per lane (lanes 2-51. Samples were separated by SDS-PAGE, transferred to a nitrocellulose membrane, and incubated with $\alpha$-pepLSF1-2. (Lane 1$) 250 \mathrm{ng}$ of His-LSF; (lane 2) $\mathrm{G}_{0}$ cell extract; (lanes 3-5) extracts from cells stimulated for 5,30 , and $60 \mathrm{~min}$, respectively. The bracket indicates the region of migration of LSF species.

of $T$ cells, and is not attributable to an increase in protein level but rather to modification of the preexisting pool of LSF. 


\section{LSF is a phosphoprotein}

Mitogenic stimulation of all cell types, including T cells, results in the induction of signal transduction cascades and the concomitant change in the phosphorylation state of many target proteins. We initially examined whether LSF is normally phosphorylated in cycling cells, to determine whether the electrophoretic mobility shift following mitogenic stimulation could be explained by an induced phosphorylation event. Western blot analysis of LSF from HeLa nuclear extract revealed at least three bands migrating where LSF was anticipated to migrate (Fig. 3A, lanes 1,6). Treatment of HeLa nuclear extract with phosphatase in vitro caused the three prominent LSF bands to shift into one band migrating faster than all of the others (Fig. 3A, cf. lane 1 with lanes 2-5). In the presence of phosphatase inhibitors, the mobilities of the LSF bands remained unchanged in the presence of increasing amounts of phosphatase (Fig. 3A, lanes 6-10). Furthermore, phosphatase treatment of nuclear extracts prepared from mitogenically stimulated human $\mathrm{T}$ cells also increased the mobility of the slower migrating, induced form of LSF to that of a faster migrating species (data not shown). These data demonstrate that the multiple species of LSF that are visualized on one-dimensional gel electrophoresis are largely, if not totally, attributable to differential phosphorylation.

To definitively demonstrate that the mobility change in LSF on mitogenic stimulation was attributable to rapid phosphorylation, human peripheral $\mathrm{T}$ cells were labeled in vivo with $\left[{ }^{32} \mathrm{P}\right]$ orthophosphate before stimulation. Extracts from equivalent numbers of unstimulated and mitogenically stimulated cells were then immunoprecipitated with a monoclonal antibody against LSF, $\alpha$-LSFmAbll, and the radio-labeled, immunoprecipitated proteins were displayed by SDS-PAGE (Fig. 3B). The antibody precipitated one band not present in control immunoprecipitations (Fig. 3B, cf. lanes 2 and 3) that migrated in the expected position for LSF (Fig. 3, lane 1). The level of LSF phosphorylation increased sixfold
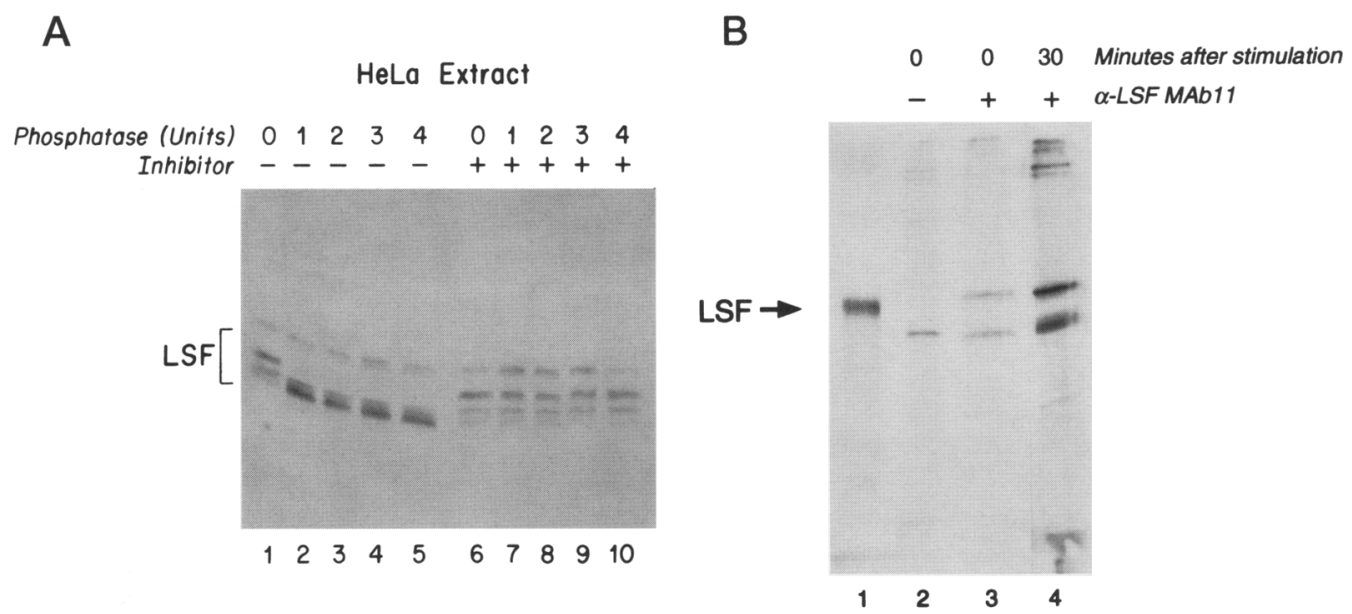

Figure 3. LSF is phosphorylated. (A) HeLa cell nuclear extract was treated with 1 to 4 units of potato acid phosphatase, as indicated, in the absence (lanes 1-5) or the presence (lanes $6-10$ ) of $2 \mathrm{~mm}$ ammonium molybdate for $30 \mathrm{~min}$ at $37^{\circ} \mathrm{C}$. Extracts were analyzed by Western blots as described in Materials and Methods. The region of migration of LSF species is indicated by the bracket. Note that the upper band was not reproducibly observed, depending on the batch of purified antibody, and therefore does not appear to represent LSF, but rather a nonspecifically reacting protein. $(B)$ LSF is phosphorylated in vivo within $30 \mathrm{~min}$ of mitogen treatment of $\mathrm{T}$ cells. Biosynthetically ${ }^{32}$ P-labeled LSF was immunoprecipitated with $\alpha$-LSFmAb11 (lanes 3,4) or without antibody (lane 2) and the pellets were analyzed by $10 \%$ SDS-PAGE. (Lane 1) In vitro-translated LSF marker (Shirra et al. 1994); (lanes 2,3) immunoprecipitates from unstimulated cell extract; (lane 4) immunoprecipitate from extract of cells stimulated for $30 \mathrm{~min}$. (C) Phosphoamino acid analysis of LSF from unstimulated cells. Biosynthetically ${ }^{32} \mathrm{P}$-labeled LSF was immunoprecipitated with $\alpha$-LSFmAb11 from unstimulated cells and processed for phosphoamino acid analysis as described in Materials and Methods. The positions of migration of the marker phosphoamino acids [(SER) phosphoserine; (THR) phosphothreonine; and (TYR) phosphotyrosine] are marked by arrows. $(D)$ Phosphoamino acid analysis of LSF from stimulated cells. Biosynthetically ${ }^{32} \mathrm{P}$-labeled LSF was immunoprecipitated with $\alpha$-LSFmAb1l from cells stimulated for $30 \mathrm{~min}$ and processed for phosphoamino acid analysis as described in Materials and Methods. The markers are indicated as in $C$.

\section{C}

$\mathrm{G}_{0}$

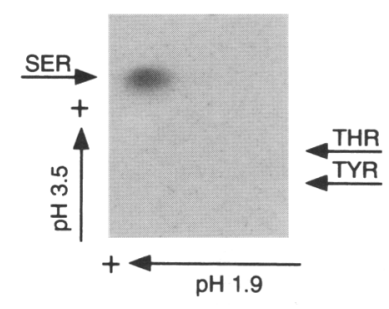

$30^{\prime}$

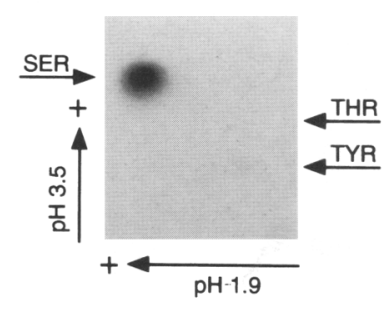


within $30 \mathrm{~min}$ of mitogenic stimulation (Fig. 3, lanes $3,4)$. Phosphorylation of LSF occurred on serine residue(s), as shown by phosphoamino acid analyses (Fig. $3 D$ ). We note that although LSF is phosphorylated on serine residue(s) in the unstimulated cell extracts (Fig. $3 \mathrm{Cl}$, the level of radio-labeled phosphoserine was always increased on mitogenic stimulation.

The rapid phosphorylation of LSF on serine residue(s) in response to mitogens suggested potential serine $\mathrm{ki}$ nases that might phosphorylate LSF in vivo. In particular, we hypothesized that LSF may be a substrate of the MAP kinase family, specifically pp $44 / 42$ (ERK1/2) (Chen et al. 1992; Davis 1993, 1994; Hill and Treisman 1995), based on the following facts. (1) The rapid kinetics of LSF modification in the nucleus after stimulation of quiescent cells mirrors the spatial and temporal activation of pp44/42 (ERK1/2); (2) pp44/42 (ERK1/2) are serine/threonine kinases, corresponding with phosphorylation of LSF on serine residue(s) in vivo; and (3) LSF contains six serine-proline dipeptide (SP) sequences, which are similar to known phosphorylation motifs for pp44/ $42(E R K 1 / 2)$. To test this hypothesis, purified, recombinant, histidine-tagged LSF (His-LSF) was incubated with pp44 (ERK1) immune complexes from either unstimulated or stimulated T cells in the presence of $\left[\gamma^{32} \mathrm{P}\right] \mathrm{ATP}$. There was minimal phosphorylation of LSF on incubation with control immune complexes precipitated without pp44 (ERK1) antibody from either unstimulated or stimulated cell extracts, or with immune complexes precipitated with pp44 (ERK1) antibody from unstimulated cell extracts (Fig. 4A, lanes 2-4). In contrast, LSF was phosphorylated effectively by pp44 (ERK1) immune complexes derived from cells stimulated for $5 \mathrm{~min}$ (Fig. 4A, lane 5). Quantitation revealed a 12-fold increase in the phosphorylation of His-LSF by pp44 (ERK1) in stimulated cell extracts compared with phosphorylation from unstimulated cell extracts. Phosphoamino acid analysis indicated that pp44 (ERK1) phosphorylated His-LSF on serine residue(s) (Fig. 4B). We note that the antibody to pp44 (ERK1) also crossreacts with pp42 (ERK2), so it is likely that both kinases are present in the immune complex assays.

\section{Phosphorylation by ERK1 in vitro mimics the rapid growth-induced phosphorylation of LSF in vivo}

Phosphotryptic peptide maps derived from phosphorylated LSF suggested that the same peptide was phosphorylated both in vitro by ERK 1 and in vivo on mitogen stimulation (data not shown). Only three tryptic peptides in LSF contain SP motifs. The size and charge of the largest peptide, derived from residues 264-339 and containing four SP motifs (Shirra et al. 1994), was most consistent with the migration of the peptide visualized on the phosphotryptic peptide maps. To determine whether this central 76-amino-acid region of LSF is in fact targeted by growth-stimulated signal transduction cascades, the serine residues at positions $278,289,291$, and 309 were mutated to alanine residues either singly or in combination. Using growth-regulated NIH 3T3 fibro-
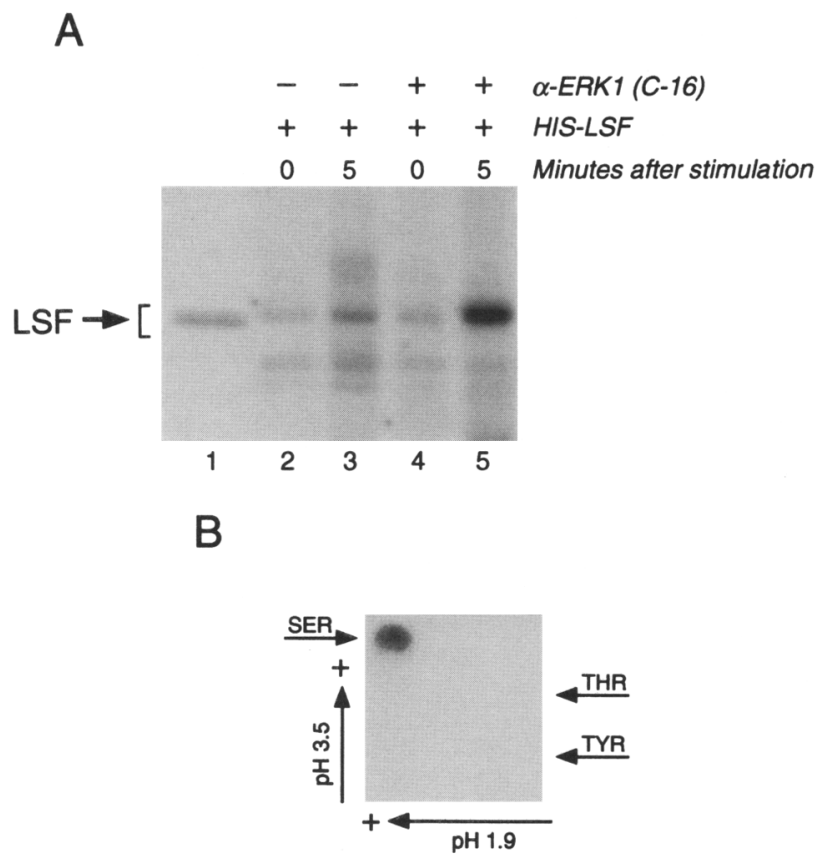

Figure 4. LSF is phosphorylated by ERK in vitro. (A) Immune complexes isolated from unstimulated (lanes 2,4 ) or stimulated (lanes 3,5) T cells in the presence (lanes 4,5) or absence (lanes $2,3)$ of antibody against pp44 (ERK1), $\alpha$-ERK1, were incubated with His-LSF and $\left[\gamma_{-}{ }^{32} \mathrm{P}\right] \mathrm{ATP}$ and the reactions separated by $10 \%$ SDS-PAGE. (Lane 1) In vitro-translated LSF marker (Shirra et al. 1994). The bracket indicates the region of migration of LSF species. Quantitation was performed on a PhosphorImager using ImageQuant software. $(B)$ Phosphoamino acid analysis of LSF phosphorylated by pp44 (ERK1) in vitro. His-LSF phosphorylated by an ERK immunoprecipitate derived from $\mathrm{T}$ cells 5 min after mitogen treatment was processed for phosphoamino acid analysis as described in Materials and Methods. The migrations of marker phosphoamino acids are indicated as in Fig. 3C.

blasts, we tested whether any of these substitution mutations would abrogate the electrophoretic mobilityshift of LSF following mitogenic stimulation (Fig. 5A). As expected, serum stimulation of quiescent fibroblasts resulted in a decrease in the electrophoretic mobility of wild-type hemagglutinin-tagged LSF (HA-LSF; Fig. 5A, lanes 3,4), although unlike the endogenous LSF, only a portion of the introduced LSF became modified. In contrast, the mobility of the mutant HA-LSF, in which all four serine residues were changed to alanine residues, was not affected by serum stimulation (Fig. 5A, lanes 5,61 , indicating that one or more of these serine residues is targeted by serum stimulation. LSF mutants containing alanine at positions 278,289 , or 309 still responded to serum stimulation by a shift in the electrophoretic mobility (Fig. 5A, lanes 7-10,13,14). However, the HALSF mutant containing a serine to alanine substitution at position 291 did not (Fig. 5A, lanes 11,12), demonstrating that phosphorylation of serine 291 is critical for the growth-regulated electrophoretic mobility shift of LSF.

Equal amounts of these same substitution mutants, in a His-LSF context (Fig. 5C), were also tested in vitro as 
A

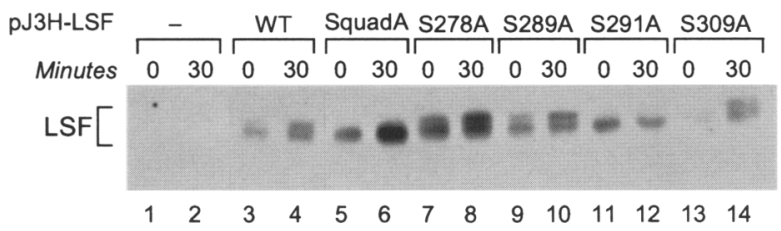

B

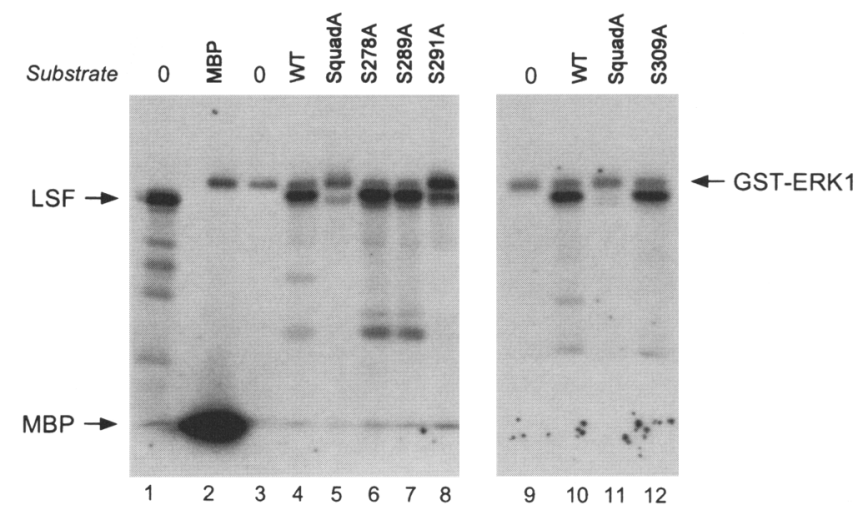

Figure 5. In vivo and in vitro phosphorylation of serine to alanine substitution mutants of LSF. (A) Western blot analysis of nuclear extracts from NIH-3T3 fibroblasts transfected with the indicated HA-LSF expression constructs. Transfected cells were growth-arrested and nuclear extracts prepared from equal numbers of either unstimulated cells (odd-numbered lanes) or cells stimulated for 30 minutes with $20 \%$ FCS (even-numbered lanes). Extracts were subjected to $10 \%$ SDS-PAGE, blotted to a nitrocellulose membrane, and probed with $12 \mathrm{CA} 5$ antibody specific to the HA tag. The region of migration of HA-LSF is indicated by the bracket. (Lanes 1,2) Mock transfected cells. (B) Purified, activated GST-ERK1 was incubated with $\left[\gamma-{ }^{32} \mathrm{P} \mid \mathrm{ATP}\right.$ and purified

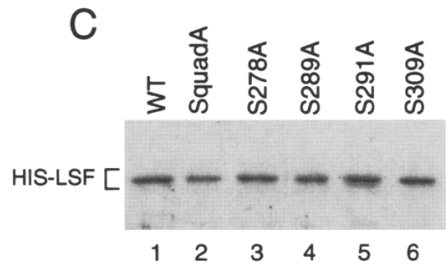
His-LSF derivatives or myelin basic protein (MBP) as substrates, and the reaction products were separated by 7.5\% SDS-PAGE. (Lane 1) In vitro-translated LSF marker (Shirra et al. 1994); (lane 2) $1 \mu \mathrm{gg}$ MBP; (lanes 3,9) control with no substrate; (lanes 4,10) wild-type His-LSF; (lanes 5,11) His-LSF quadruple substitution mutant: S278A, S289A, S291A, and S309A; (lane 6) His-LSF S278A; (lane 7) His-LSF S289A; (lane 8) His-LSF S291A; and (lane 12) His-LSF S309A. The positions of migration of His-LSF, MBP, and GST-ERK1 are marked. $(C)$ Two micrograms each of the same preparations of His-LSF proteins used in $(B)$ were electrophoresed through a $7.5 \%$ SDS-PAGE and stained with coomassie blue. His-LSF protein derivatives are as labeled.

substrates in a pp44 (ERK1) kinase assay. Activated GST-pp44 (ERK1), purified from 293 cells, efficiently phosphorylated wild-type His-LSF in vitro, in addition to its autophosphorylation (Fig. 5B, lanes 3,4,9,10). However, there was minimal phosphorylation by pp44 (ERK1) of His-LSF that was quadruply mutated at the four central serine residues (Fig. 5B, lanes 5,11 ). As with in vivo modification, His-LSF mutants containing serine to alanine substitutions at positions 278,289 , or 309 were still phosphorylated (Fig. 5B, lanes $6,7,12$ ), but there was a marked decrease in the amount of phosphorylation by pp44 (ERK1) on the His-LSF mutant with a serine to alanine change at position 291 (Fig. 5B, lane 8). The amino acid sequence around this phosphorylation site is as follows: ${ }_{285}$ YVNNSPSPGFN $_{295}$ (the serine residue at position 291 is in bold). These in vivo and in vitro data demonstrate that the central SP motifs of LSF are the target of growth stimulation in vivo and of pp44 (ERK1) in vitro and that the serine residue at position 291 is crucial for complete phosphorylation of the protein in both cases. These data therefore implicate pp $44 / 42$ (ERK1/2) as the kinases that mediate LSF modification in vivo.

\section{Dephosphorylation of LSF diminishes its DNA-binding activity}

The kinetics of LSF phosphorylation in stimulated T cells are similar to the kinetics of increased LSF-DNA- binding activity, but not identical (Fig. 2, cf. B with A), suggesting that LSF may be the target of multiple modes of regulation on mitogenic stimulation. Therefore, to determine whether there is a causal relationship between phosphorylation and enhancement in DNA-binding activity, HeLa nuclear extract was treated in vitro with phosphatase, followed by gel mobility-shift analysis with the LSF-280 DNA-binding site. In phosphatasetreated extracts, the level of LSF-DNA-binding activity dropped sharply, as compared with mock-treated extracts (Fig. 6A, lanes 1,2). However, in extracts that were treated not only with phosphatase but also with phosphatase inhibitors, the level of LSF-DNA-binding activity changed minimally (Fig. 6A, lanes 3,4). These experiments suggest that phosphorylation of LSF, at least at particular sites, directly increases its DNA-binding activity.

To verify that effects of phosphatase on LSF-DNAbinding activity were specifically attributable to dephosphorylation of LSF and not to effects of the phosphatase preparation on other proteins contained in the nuclear extracts, a highly purified preparation of LSF from HeLa cells was treated with phosphatase and the same sample was assayed both for the modification state of LSF and for DNA-binding activity. Analysis of the protein by Western blotting demonstrated three LSF bands in the nontreated sample (Fig. 6C, lane 1). Treatment with phosphatase caused a shift from the upper two bands to a faster migrating species (Fig. 6C, lane 2). As antici- 
$A$

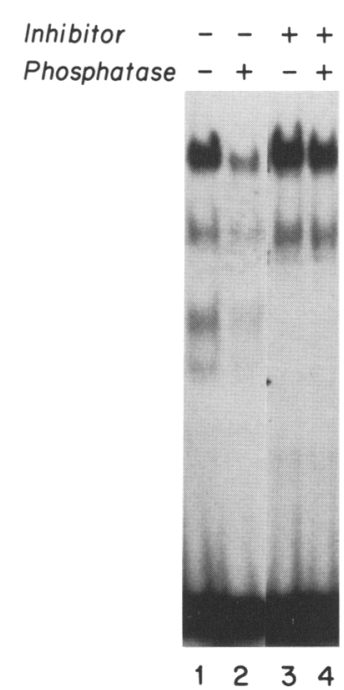

B

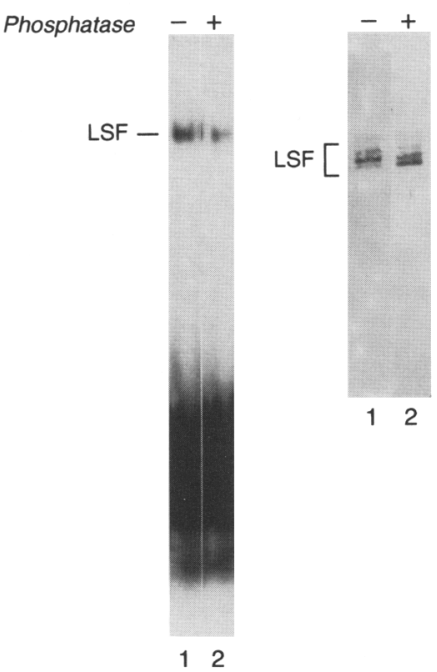

Figure 6. Reduction in DNA-binding activity on dephosphorylation of LSF. (A) Phosphatase treatment of HeLa nuclear extracts reduces LSF-DNA-binding activity. HeLa nuclear extract was treated with calf intestinal phosphatase (lanes 2,4) in the absence (lanes 1,2) or the presence (lanes 3,4) of phosphatase inhibitors. Samples were analyzed in a gel mobility-shift assay as described in Materials and Methods. LSF-DNA complexes are the slowest migrating complexes in the gel. Free DNA is shown at the bottom of the gel. $(B)$ Phosphatase treatment of purified LSF reduces its DNA-binding activity. A purified preparation of LSF from HeLa cells was incubated in the absence (lane 1) or the presence (lane 2) of calf intestinal phosphatase. Samples were subjected to gel mobility-shift analysis as described in Materials and Methods. $(C)$ Dephosphorylation of purified LSF increases its electrophoretic mobility. The same samples of purified LSF and purified dephosphorylated LSF used for $B$ were subjected to Western blot analysis as described in Materials and Methods. (Lane 1) No phosphatase; (lane 2) treated with calf intestinal phosphatase.

pated, the phosphatase-treated sample contained a lower level of LSF-DNA-binding activity than the untreated sample (Fig. 6B, lanes 1,2). These data confirm that LSFDNA-binding activity is decreased when LSF itself is dephosphorylated. Probably attributable to the partial dephosphorylation of LSF during the purification procedures, the reduction in LSF-DNA-binding activity on phosphatase treatment was not as striking as observed in crude extracts (Fig. 6, cf. A with B). It is important to note that the DNA-binding activity in either a crude or purified state was never abolished completely on dephosphorylation of LSF, consistent with the ability of LSF produced in bacteria to bind to DNA.

\section{Discussion}

Transcription factors are crucial targets of mitogenic signal transduction cascades (Hunter and Karin 1992; Davis 1993; Hill and Treisman 1995; Hunter 1995). Here we have shown that the mammalian transcription factor
LSF is one such target. LSF is a phosphoprotein that is phosphorylated rapidly on serine residues in human $T$ cells following mitogenic stimulation. Our data strongly suggest that LSF is a target of the MAP kinase pp44/42 (ERK $1 / 2)$ in vivo. The DNA-binding activity of LSF is concomitantly stimulated in vivo, by approximately fivefold within $30 \mathrm{~min}$ of stimulation. In vitro phosphatase experiments support the relevance of the in vivo correlation between phosphorylation and enhancement of DNA-binding activity. These data suggest a link between a major mitogenic signaling pathway and phosphorylation of LSF and support the hypothesis that LSF has a biological role in growth stimulation of resting cells, and in particular, of human peripheral $\mathrm{T}$ cells.

\section{Enhanced LSF-DNA-binding activity results from direct phosphorylation of the LSF gene product}

Our data indicate that the increase in LSF-DNA-binding activity is directly attributable to the phosphorylation of the LSF (CP2/LBP-lc) gene product. First, rapid phosphorylation of LSF in vivo as a result of mitogenic stimulation is accompanied by a dramatic increase in LSFDNA-binding activity. Second, dephosphorylation of either highly purified HeLa LSF or LSF from HeLa nuclear extract diminishes its DNA-binding activity. Furthermore, the majority of the LSF-DNA-binding activity in cells is attributable to a homomultimer of LSF (Shirra et al. 1994), arguing against the possibility that dramatic alterations of LSF-DNA-binding activity would be attributable to modifications of a partner protein.

Phosphorylation of proteins has been shown to induce conformational changes (Kapiloff et al. 1991; Manak and Prywes 1991) or overcome internal inhibitory interactions (Abdel-Hafiz et al. 1992), either of which could lead to higher DNA-binding activity. The site of phosphorylation of LSF lies immediately carboxy-terminal of the presumed DNA-binding surface (Uv et al. 1994; Shirra 1995) consistent with either of these models. It is also possible that the rapid phosphorylation of LSF seen on mitogenic stimulation might modulate additional LSF activities. For example, phosphorylation of c-Jun at multiple sites attributable to a signal transduction cascade increases both the DNA-binding activity of the factor and its transactivation potential (Pulverer et al. 1991; Lin et al. 1992; Hibi et al. 1993; Dérijard et al. 1994; Minden et al. 1994).

\section{Phosphorylation sites in LSF}

Based on phosphotryptic peptide analyses, we hypothesized that the central 76-amino-acid peptide containing four serine-proline motifs in LSF was the target of a growth-induced signal transduction cascade. The mutagenesis data indicated that serum stimulation of quiescent cells resulted in a decreased electrophoretic mobility of wild-type LSF or mutant proteins containing a serine to alanine substitution at positions 278,289 , or 309 . However, serum stimulation of quiescent cells containing either mutant LSF with serine to alanine changes at 
all four positions or mutant LSF with a serine to alanine change at only position 291 did not alter the mobility of the introduced proteins. Furthermore, mutation of all four serine-proline motifs in this region to alanine-proline completely abolished phosphorylation in vitro by pp44 (ERK1), indicating that this peptide is the sole target of this kinase. Although the single serine to alanine substitution at position 291 decreased markedly the amount of phosphorylation by pp44 (ERK1), residual phosphorylation was clearly higher than in the quadruply mutated LSF. Taken together, our data indicate that serine 291 is the major target of phosphorylation by ERK1/2 and is critical for the growth-induced modification of LSF in cells.

\section{Phosphorylation of LSF by MAP kinase}

Several lines of evidence strongly suggest that either pp44/42 (ERK1/2) or another member of the MAP kinase family with a similar substrate specificity and activation profile is involved in phosphorylating LSF after mitogenic stimulation in vivo. First, the spatial and temporal activity of pp44/42 (ERK1/2) correlates with the stimulation of LSF-DNA-binding activity by phosphorylation (Chen et al. 1992; Davis 1993; Hill and Treisman 1995). Biochemical fractionations and immunofluorescence $\mid Q$. Zhu and U. Hansen, unpubl.) indicate that LSF is a nuclear protein. On mitogen induction, pp44/42 (ERK1/ 2) is rapidly phosphorylated and translocated to the nucleus (Chen et al. 1992; Davis 1993; Hill and Treisman 1995). The rapidity of LSF phosphorylation, within $5 \mathrm{~min}$ of mitogen stimulation, correlates well with the temporal peak in pp44/42 (ERK1/2) activity. Second, LSF is phosphorylated on serine 291 both by pp44 (ERK1) in vitro and on mitogenic stimulation in vivo. Third, stimulation of T cells with PMA alone was sufficient to phosphorylate LSF within 5 min. However, stimulation with PHA and ionomycin, either in combination or individually, did not affect the mobility of LSF with such rapid kinetics (data not shown). The pp44/42 (ERK1/ ERK2), but not the Jun, kinases are activated by phorbol esters alone in T lymphocytes (Su et al. 1994).

Despite this preponderance of evidence, our data do not unequivocally prove that the pp44/42 (ERK1/2) are the kinases that phosphorylate LSF in vivo. Both Jun kinase and p38 kinase can also phosphorylate LSF on serine 291 in vitro (J. Volker and U. Hansen, unpubl.). Therefore, further experiments, currently underway, are required to test directly the involvement of the ras/raf/ ERK signal transduction pathway in the biological induction of LSF.

\section{Potential biological role for LSF in growth stimulation of $T$ cells}

A biological role for LSF in $T$ cells is suggested both by its rapid phosphorylation on mitogenic stimulation, presumably by pp44/42 (ERK1/2), and by the profile of LSFDNA-binding activity, peaking within $15 \mathrm{~min}$, and remaining high for at least another $3 \mathrm{hr}$. These data, coupled with the intriguing locations of DNA-binding sites for LSF within the c-fos and ODC promoters, which are induced as immediate early/early events in $\mathrm{T}$ cells (see Introduction), lead us to hypothesize that LSF contributes to the regulation of such promoters during the $\mathrm{G}_{0}$ to $\mathrm{G}_{1}$ transition. The LSF-DNA-binding sites within the $\mathrm{c}$-fos and ODC promoters are both conserved in their sequence and in their locations from mouse to human. Deletion analysis of the ODC promoter revealed that a $90-b p$ region of the promoter containing the LSF-DNAbinding site was responsible for serum and TPA induction of the ODC gene (Mar et al. 1995). Collectively, these observations suggest that LSF is the downstream target of a MAP kinase signal transduction cascade, that LSF contributes to the regulation of immediate early and/or early genes, and that LSF therefore has an important role as a cell growth regulator.

\section{Materials and methods}

Cell culture

Human peripheral T cells were isolated by layering human donor blood (from the Dana-Farber Cancer Institute Blood Component Lab) onto Ficoll-paque cushions as described by the manufacturer (Pharmacia). Cells were washed in RPMI 1640 medium (GIBCO) supplemented with $2.5 \%$ heat-inactivated fetal calf serum (FCS; Bio-Whitakker) and separated from contaminating lymphocytes by culturing on plastic dishes in RPMI 1640 supplemented with $10 \%$ heat-inactivated FCS at $37^{\circ} \mathrm{C}$ in $5 \% \mathrm{CO}_{2}$ for $2 \mathrm{hr}$. Nonadherent cells were cultured further at a concentration of $1 \times 10^{7}$ cells $/ \mathrm{ml}$ and stimulated at indicated times with $2 \mu \mathrm{g} / \mathrm{ml}$ of phytohemagglutinin (PHA; Murex Diagnostics), $0.12 \mu \mathrm{M}$ phorbol myristate acetate (PMA; Sigma), and $0.12 \mu \mathrm{g} / \mathrm{ml}$ of ionomycin (CalBiochem).

$\mathrm{NIH}-3 \mathrm{~T} 3$ fibroblasts were cultured in Dulbecco's modified Eagle medium (DMEM) supplemented with $10 \%$ calf serum (CS; JRH Biosciences) at $37^{\circ} \mathrm{C}$ in $10 \% \mathrm{CO}_{2}$. For transfection, $3 \times 10^{6}$ cells were treated with $12 \mu \mathrm{g}$ of total DNA and $35 \mu \mathrm{l}$ of lipofectamine (GIBCO) as described by the manufacturer. Eighteen hr after transfection, cells were starved for $48 \mathrm{hr}$ in DMEM supplemented with $0.5 \%$ CS.

\section{Nuclear extracts}

Nuclear extracts were prepared as described (Andrews and Faller 1991), with the following modifications: $4 \times 10^{7}$ (HeLa), $1 \times 10^{8}(\mathrm{~T})$, or $3 \times 10^{6}(\mathrm{NIH} 3 \mathrm{~T} 3)$ cells were swelled on ice in hypotonic buffer and lysed in a Dounce homogenizer (HeLa) or lysed by vortexing for $10 \mathrm{sec}$ ( $\mathrm{T}$ and $\mathrm{NIH}-3 \mathrm{~T} 3$ ). Nuclei were resuspended in a high salt buffer (Andrews and Faller 1991) with the following additions: $2 \mathrm{mM} \mathrm{Na}_{3} \mathrm{VO}_{4}, 2 \mathrm{mM} \mathrm{Na}_{2} \mathrm{P}_{2} \mathrm{O}_{7}, 1 \mathrm{~mm}$ $\mathrm{NaF}$, and $50 \mathrm{~mm} \beta$-glycerophosphate, incubated on ice for 20 min, and pelleted. The supernatant was frozen in liquid nitrogen and stored at $-70^{\circ} \mathrm{C}$. Final protein concentrations were between 2 and $4 \mathrm{mg} / \mathrm{ml}$ in a total volume of $50 \mu \mathrm{l}$ of extract.

\section{Antibody production}

Antipeptide antibodies to LSF were generated against the synthetic peptides $\mathrm{NH}_{2}$-CLPLADEVIETGLVQD-COOH (pep1, amino acids 7-21), and $\mathrm{NH}_{2}$-CDETLTYLNQGQSYEIR-COOH (pep2, amino acids 83-98) (Shirra et al. 1994). Two rabbits were immunized with each peptide conjugated to chicken serum al- 
bumin, using sulfo-MBS (Pierce) as a cross-linking reagent. Antibodies against pepl were affinity purified as described / Harlow and Lane 1988). For $\alpha$-pepLSF1-1, whole sera from immunized rabbits were precipitated, dialyzed, and affinity purified against pepl. Antibody against pep2, $\alpha$-pepLSF2-1, was IgG purified (Harlow and Lane 1988). $\alpha$-LSFmAb11 monoclonal antibody supernatant was generated against recombinant, purified, His-LSF as described (Harlow and Lane 1988).

\section{Western blot analysis}

Proteins were separated by $7.5 \%$ or $10 \%$ SDS-PAGE for $12 \mathrm{hr}$ at $25 \mathrm{~mA}$ at $4^{\circ} \mathrm{C}$ and transferred to a nitrocellulose membrane (Schleicher \& Schuell) for $4 \mathrm{hr}$ at $100 \mathrm{~V}$ at $4^{\circ} \mathrm{C}$. For immunoblots using LSF antibodies, nitrocellulose membranes were blocked for $1 \mathrm{hr}$ in $3 \%$ gelatin in Tris-buffered saline (TBS): $150 \mathrm{~mm}$ $\mathrm{NaCl}, 10 \mathrm{~mm}$ Tris- $\mathrm{HCl}(\mathrm{pH} 8.0)$, incubated with a $1 / 1000$ dilution of $\alpha$-pepLSF $1-1$ in TBS plus $0.05 \%$ Tween 20 (TBST) for 12 hr, washed three times in TBST, incubated with anti-rabbit antibody conjugated to horse radish peroxidase (Bio-Rad), and visualized by chemiluminescence as described by the supplier (Dupont NEN). For HA tag protein blots, nitrocellulose membranes were blocked in $5 \%$ dried milk in TBS plus $0.25 \%$ Tween 20 , incubated with a $1 / 1000$ dilution of $12 \mathrm{CA} 5$ antibody (BAbCo), and visualized as described above.

\section{Gel mobility-shift assays}

For highly purified HeLa LSF, 1 ng of protein was pre-incubated at room temperature for $10 \mathrm{~min}$ in $1.2 \% \mathrm{NP}-40,127 \mathrm{mM} \mathrm{KCl}, 8$ mM Tris- $\mathrm{HCl}$ (pH 8.0), 20 mM HEPES [4-(2-hydroxyethyl)-1-piperazineethane sulfonic acid] $(\mathrm{pH} 7.9), 21.3 \%$ glycerol, $0.18 \mathrm{~mm}$ EDTA, $2 \%$ polyvinyl alcohol, $0.86 \mathrm{~mm}$ dithiothreitol (DTT), and $0.1-1 \mu \mathrm{g}$ of poly $[\mathrm{d}(\mathrm{I}-\mathrm{C})] \cdot \operatorname{poly}[\mathrm{d}(\mathrm{I}-\mathrm{C})]$ in a final volume of 15 $\mu$ l. Subsequently, 16 fmoles of ${ }^{32} \mathrm{P}$-labeled oligonucleotide containing the LSF-280-binding site (Huang et al. 1990 ) was added, and the reactions were incubated for an additional $30 \mathrm{~min}$. Samples were electrophoresed through a $5 \%$ polyacrylamide gel for $2 \mathrm{hr}$ at $11 \mathrm{~V} / \mathrm{cm}$ in buffer containing $44.5 \mathrm{~mm}$ Tris base, 44.5 $\mathrm{mM}$ boric acid, and $1 \mathrm{mM}$ EDTA.

For T cell or HeLa extracts, $7.5 \mu \mathrm{g}$ or $5 \mu \mathrm{g}$ of extract, respectively, was pre-incubated as indicated above, except that $1 \mu \mathrm{g}$ of poly $[\mathrm{d}(\mathrm{I}-\mathrm{C})] \cdot[\mathrm{d}(\mathrm{I}-\mathrm{C})]$ was added per reaction. Subsequent steps were as described above.

\section{Phosphatase assays}

For HeLa nuclear extract used in gel mobility-shift assays, phosphatase reactions were performed as follows: $12.5 \mu \mathrm{g}$ of $\mathrm{HeLa}$ nuclear extract was incubated for $30 \mathrm{~min}$ at $37^{\circ} \mathrm{C}$ in a buffer containing $10 \mathrm{~mm}$ Tris- $\mathrm{HCl}(\mathrm{pH} 8.0), 2 \mu \mathrm{g} / \mathrm{ml}$ of aprotinin, 0.5 $\mu \mathrm{g} / \mathrm{ml}$ of leupeptin, $0.5 \mathrm{~mm}$ phenylmethylsulfonyl flouride (PMSF), and phosphatase inhibitors, where indicated, at final concentrations of $50 \mathrm{~mm} \mathrm{NaF}, 0.2 \mathrm{mM} \mathrm{Na}_{3} \mathrm{VO}_{4}$, and $50 \mathrm{~mm}$ $\beta$-glycerophosphate, in a final reaction volume of $25 \mu$ l. Reactions were incubated with or without one unit of calf intestinal alkaline phosphatase conjugated to agarose beads (Sigmal. Ten microliters of the reaction (equivalent to $5 \mu \mathrm{g}$ of extract) was subjected to gel mobility-shift analysis as described above, except that the final reaction volume was $30 \mu l$.

For HeLa nuclear extract used in Western analysis, phosphatase reactions were performed as follows: $55 \mu \mathrm{g}$ of HeLa nuclear extract was incubated for $30 \mathrm{~min}$ at $37^{\circ} \mathrm{C}$ in a buffer containing $10 \mathrm{mM}$ PIPES [piperazine-N, $\mathrm{N}^{\prime}$-bis (2-ethanesulfonic acid)] $[\mathrm{pH}$ $6.01,2 \mu \mathrm{g} / \mathrm{ml}$ of aprotinin, $0.5 \mu \mathrm{g} / \mathrm{ml}$ of leupeptin, $0.5 \mathrm{~mm}$ PMSF, and $2 \mathrm{~mm}$ ammonium molybdate, where indicated, as a phos- phatase inhibitor. Reactions were incubated with or without 1 to 4 units of potato acid phosphatase (Sigma) in a final reaction volume of $50 \mu$ l. Forty-five microliters of the reaction was subjected to SDS-PAGE and Western blotting analysis as described.

For purified LSF, phosphatase reactions were performed as follows: $\sim 4 \mathrm{ng}$ of highly purified LSF was incubated for $30 \mathrm{~min}$ at $37^{\circ} \mathrm{C}$ in a buffer containing $50 \mathrm{~mm}$ Tris $-\mathrm{HCl}(\mathrm{pH} 8.8), 12 \mathrm{~mm}$ HEPES (pH 7.9), $0.9 \mathrm{mM} \mathrm{MgCl}_{2}, 15 \%$ glycerol, $250 \mathrm{~mm} \mathrm{NaCl}$, $0.12 \mathrm{~mm}$ EDTA, $0.3 \mathrm{~mm}$ DTT, $1 \% \mathrm{NP}-40,2 \mu \mathrm{g} / \mathrm{ml}$ of aprotinin, $0.5 \mu \mathrm{g} / \mathrm{m}$ l of leupeptin, $0.5 \mathrm{mM}$ PMSF, and 4 units of calf intestinal alkaline phosphatase conjugated to agarose beads (Sigma), where indicated. Final reaction volumes were $50 \mu \mathrm{l}$. Four microliters of the reaction was subjected to gel mobility-shift analysis and $40 \mu$ of the reaction were separated by $10 \%$ SDSPAGE and immunoblotted as described.

\section{In vivo labeling, immunoprecipitation reactions, and phosphoamino acid analysis}

For $\left[{ }^{35} \mathrm{~S}\right]$ methionine labeling, a $100-\mathrm{mm}$ plate of HeLa cells (gift of R. Weinberg, Massachusetts Institute of Technology, Boston| was incubated for $4 \mathrm{hr}$ in DMEM containing $\left[{ }^{35} \mathrm{~S}\right]$ methionine at a final concentration of $100 \mu \mathrm{Ci} / \mathrm{ml}$. Extracts were prepared by lysis in a buffer containing 1\% NP-40, $50 \mathrm{~mm}$ HEPES (pH 7.5), $300 \mathrm{~mm} \mathrm{NaCl}, 1 \mathrm{~mm}$ EGTA, $1.5 \mathrm{~mm} \mathrm{MgCl}_{2}, 2 \mu \mathrm{g} / \mathrm{ml}$ of aprotinin, $0.5 \mu \mathrm{g} / \mathrm{ml}$ of leupeptin, and $0.5 \mathrm{~mm}$ PMSF, and diluted in the same buffer lacking $\mathrm{NaCl}$ to bring the extracts to a final salt concentration of $150 \mathrm{mM} \mathrm{NaCl}$. Lysates were clarified for $3 \mathrm{hr}$ by incubating with $3 \mu \mathrm{l}$ of pre-immune serum and $50 \mu \mathrm{l}$ of $50 \%$ protein A-Sepharose (CL4B, Pharmacia). One milliliter of the precleared supernatants $\left(-1 \times 10^{8} \mathrm{cpm}\right)$ was incubated for $1 \mathrm{hr}$ with $3 \mu$ l of $\alpha$-pepLSF1-1 or $\alpha$-pepLSF2-1 antisera with $30 \mu l$ of $50 \%$ protein A-Sepharose. Precipitates were washed with a buffer containing $20 \mathrm{~mm}$ HEPES (pH 7.5), $150 \mathrm{~mm} \mathrm{NaCl}$, and $0.1 \%$ NP-40, and separated by $10 \%$ SDS-PAGE as described.

For ${ }^{32} \mathrm{P}_{\mathrm{i}}$ labeling and phosphoamino acid analysis, quiescent $\mathrm{T}$ cells were starved in phosphate-free RPMI containing $10 \%$ dialyzed, heat-inactivated FCS for $30 \mathrm{~min}$ at $37^{\circ} \mathrm{C}$. Cells were pelleted, resuspended to a final cell concentration of $1 \times 10^{8}$ cells $/$ $\mathrm{ml}$ in $10 \mathrm{ml}$ of phosphate-free RPMI containing $10 \%$ dialyzed, heat-inactivated FCS, $20 \mathrm{~mm}$ HEPES $\{\mathrm{pH} 7.0\}$, and $25 \mathrm{mCi}$ of ${ }^{32} \mathrm{P}$ ]orthophosphate $(8000 \mathrm{Ci} / \mathrm{mmole} ; \mathrm{NEN})$ and incubated for 3 hr at $37^{\circ} \mathrm{C}$. Cells were subsequently stimulated for $30 \mathrm{~min}$ as described above. Equal numbers of unstimulated and stimulated cells were washed twice with a buffer containing $150 \mathrm{mM} \mathrm{NaCl}$ and $20 \mathrm{mM}$ HEPES $(\mathrm{pH} 7.01$, resuspended in $500 \mu \mathrm{l}$ of lysis buffer [10 m.M HEPES (pH 7.6), $100 \mathrm{~mm} \mathrm{NaCl}, 1 \%$ Triton X-100, $2 \mathrm{~mm}$ $\mathrm{Na}_{3} \mathrm{VO}_{4}, 50 \mathrm{~mm} \beta$-glycerophosphate, $1 \mathrm{~mm} \mathrm{NaF}, 0.1 \mathrm{mg} / \mathrm{ml}$ of aprotinin, $0.1 \mathrm{mg} / \mathrm{ml}$ of leupeptin, and $0.18 \mathrm{~mm}$ PMSF] and incubated on ice for $30 \mathrm{~min}$. Lysates were centrifuged at $4^{\circ} \mathrm{C}$ for 20 min at $16000 \mathrm{~g}$ to pellet cell debris. The supernatent was combined with $500 \mu 1$ of lysis buffer, $300 \mu$ l of $\alpha$-LSFmAbl1 supernatant, $1 \mu \mathrm{g}$ of goat anti-mouse IgA + IgG + IgM $[(\mathrm{H}+\mathrm{L})$, |Kirkgaard and Perry), and $50 \mu \mathrm{l}$ of a $50 \%$ slurry of protein A-Sepharose and incubated at $4{ }^{\circ} \mathrm{C}$ for $60 \mathrm{~min}$ with rocking. Immunoprecipitates were washed and were separated by $10 \%$ SDS-PAGE. The gels were dried, fixed, and autoradiographed. Gel slices containing LSF were excised from the dried gel and prepared for phosphoamino acid analysis exactly as described (Boyle et al. 1991). Samples were autoradiographed; the positions of the phosphoamino acid standards were determined with $2 \%$ ninhydrin (Sigma).

\section{MAP kinase assays}

For in vitro pp44 (ERK1) immune complex assays, $1 \times 10^{8}$ human peripheral $\mathrm{T}$ cells, either unstimulated or stimulated for 5 
min, were lysed in RIPA buffer $(140 \mathrm{~mm} \mathrm{NaCl}, 2.7 \mathrm{~mm} \mathrm{KCl}, 8$ $\mathrm{mm} \mathrm{NaH} \mathrm{PO}_{4}, 1.5 \mathrm{mM} \mathrm{KH}_{2} \mathrm{PO}_{4}, 1 \% \mathrm{NP}-40,0.5 \%$ sodium deoxycholate, $0.1 \%$ SDS, $0.5 \%$ Triton X-100, $0.2 \mathrm{~mm}$ PMSF, $2 \mathrm{mM}$ $\mathrm{Na}_{3} \mathrm{VO}_{4}, 1 \mathrm{~mm} \mathrm{NaF}$, and $50 \mathrm{~mm} \beta$-glycerophosphate). Extracts were incubated with $\alpha$-ERK 1 (c-16) antibody (Santa Cruz Biotech) and protein A-Sepharose as recommended by the manufacturer. Immune complexes containing pp44 (ERK1) were washed three times in RIPA buffer, two times in 20 mM HEPES (pH 7.2), $10 \mathrm{mM} \mathrm{MgCl}_{2}$, and then resuspended in $30 \mu$ l of kinase buffer containing: $10 \mathrm{mM} \mathrm{MgCl}_{2}, 20 \mathrm{mM}$ HEPES (pH 7.2), $0.1 \mathrm{mg}$ of BSA, $0.1 \mathrm{mg} / \mathrm{ml}$ of aprotinin, $0.1 \mathrm{mg} / \mathrm{ml}$ of leupeptin, $0.2 \mathrm{~mm}$ PMSF, $2 \mathrm{mM} \mathrm{Na}_{3} \mathrm{VO}_{4}, 1 \mathrm{~mm} \mathrm{NaF}$, and $50 \mathrm{~mm} \beta$-glycerophosphate, $1 \mu \mathrm{g}$ of His-LSF, and $10 \mu \mathrm{Ci}$ of $\left[\gamma-{ }^{32} \mathrm{P}\right] \mathrm{ATP}$, followed by incubation at $30^{\circ} \mathrm{C}$ for $20 \mathrm{~min}$ (Chung et al. 1991; Chen et al. 1992, 1993). Samples were separated by $10 \%$ SDS-PAGE and autoradiographed.

For in vitro glutathione $S$-transferase (GST)-pp44 (ERKl) assays, $200 \mathrm{ng}$ of GST-ERK1, purified and activated as described (Tanaka et al. 1995), was incubated with $2 \mu \mathrm{g}$ of His-LSF substrate in $20 \mu \mathrm{l}$ of kinase buffer containing: $20 \mathrm{mM} \mathrm{HEPES} / \mathrm{pH}$ $7.21,20 \mathrm{~mm} \mathrm{MgCl}_{2}, 2 \mathrm{~mm}$ DTT, $100 \mu \mathrm{M} \mathrm{ATP}$, and $10 \mu \mathrm{Ci}$ $\left[\gamma^{-32} \mathrm{P}\right] \mathrm{ATP}$, followed by incubation at $30^{\circ} \mathrm{C}$ for $20 \mathrm{~min}$. Samples were separated by $7.5 \%$ SDS-PAGE and autoradiographed.

\section{Constructs}

Site directed mutants of LSF under the control of a cytomegalovirus (CMV) promoter $(\mathrm{Q}$. Zhu and U. Hansen, in prep.) were obtained by PCR using mutated oligonucleotides. The mutants were made with the following codon changes: S278A $=$ TCT to GCT; S289A = TCC to GCC; S291A = TCA to GCA; and $\mathrm{S} 309 \mathrm{~A}=\mathrm{TCA}$ to GCA. The mutations were confirmed by sequencing the region that was generated by PCR. The mutant LSF regions were subcloned by fragment exchange into a Histagged LSF bacterial expression vector (Qiagen) and into a p/ $3 \mathrm{H}$ vector (Sells and Chernoff 1995), encoding an HA-tagged LSF under the control of the SV40 promoter. The mutations were confirmed by sequencing.

\section{Acknowledgments}

We thank J. Gan, C.M.H. Powell, and M.K. Shirra for assistance with antibody production and characterization; E.E. Drouin for antibody production and characterization and for the $\mathrm{pJ} 3 \mathrm{H}$ wildtype LSF construct; and Bruce Mayer for the generous gift of 293 cell lysates containing activated GST-ERK1. This research was supported by grants from the National Cancer Institute (CA38038) and the Sandoz/Dana Farber Cancer Institute (DFCI) Drug Discovery Program to U.H. L.R. was supported by the Conselho Nacional de Desenvolvimento Cientifico \& Technologico (CNPq) of the Ministry for Science and Technology of Brazil. J.L.V. was supported, in part, by National Institutes of Health grant T32-CA09361.

The publication costs of this article were defrayed in part by payment of page charges. This article must therefore be hereby marked "advertisement" in accordance with 18 USC section 1734 solely to indicate this fact.

\section{References}

Abdel-Hafiz, H.A.-M., L.E. Heasley, J.M. Kyriakis, J. Avruch, D.J. Kroll, G.L. Johnson, and J.P. Hoeffler. 1992. Activating transcription factor-2 DNA-binding activity is stimulated by phosphorylation catalyzed by $\mathrm{p} 42$ and $\mathrm{p} 54$ microtubule-associated protein kinases. Mol. Endocrinol. 6: 2079-2089.
Abrahamsen, M.S. and D.R. Morris. 1990. Cell type-specific mechanisms of regulating expression of the ornithine decarboxylase gene after growth stimulation. Mol. Cell. Biol. 10: 5525-5528.

Andrews, N.C. and D.V. Faller. 1991. A rapid micropreparation technique for extraction of DNA-binding proteins from limiting numbers of mammalian cells. Nucleic Acids Res. 19: 2499.

Boulton, T.G., Z. Zhong, Z. Wen, J.E. Darnell Jr., N. Stahl, and G.D. Yancopoulos. 1995. STAT3 activation by cytokines utilizing gp 130 and related transducers involves a secondary modification requiring an $\mathrm{H} 7$-sensitive kinase. Proc. Natl. Acad. Sci. 92: 6915-6919.

Boyle, W.J., P. Van Der Geer, and T. Hunter. 1991. Phosphopeptide mapping and phosphoamino acid analysis by two-dimensional separation of thin-layer cellulose plates. Methods Enzymol. 201: 110-149.

Chellappan, S.P., S. Hiebert, M. Mudryi, J.M. Horowitz, and J.R. Nevins. 1991. The E2F transcription factor is a cellular target for the RB protein. Cell 65: 1053-1061.

Chen, R.-H., C. Sarnecki, and J. Blenis. 1992. Nuclear localization and regulation of erk- and rsk-encoded protein kinases. Mol. Cell. Biol. 12: 915-927.

Chen, R.-H., C. Abate, and J. Blenis. 1993. Phosphorylation of the c-Fos transrepression domain by mitogen-activated protein kinase and 90-kDa ribosomal S6 kinase. Proc. Nat1. Acad. Sci. 90: 10952-10956.

Chung, J., R.-H. Chen, and J. Blenis. 1991. Coordinate regulation of $\mathrm{pp} 90^{\mathrm{rsk}}$ and a distinct protein-serine/threonine kinase activity that phosphorylates recombinant $\mathrm{pp} 90^{\text {rsk }}$ in vitro. Mol. Cell. Biol. 11: 1868-1874.

Crabtree, G.R. 1989. Contingent genetic regulatory events in T lymphocyte activation. Science 243: 355-361.

David, M., E. Petricoin III, C. Benjamin, R. Pine, M.J. Weber, and A.C. Larner. 1995. Requirement for MAP kinase (ERK2) activity in interferon $\alpha$ - and interferon $\beta$-stimulated gene expression through STAT proteins. Science 269: 1721-1723.

Davis, R.J. 1993. The mitogen-activated protein kinase signal transduction pathway. J. Biol. Chem. 268: 14553-14556. 1994. MAPKs: New JNK expands the group. Trends Biochem. Sci. 19: 470-473.

Dérijard, B., M. Hibi, I.-H. Wu, T. Barrett, B. Su, T. Deng, M. Karin, and R.J. Davis. 1994. JNK1: A protein kinase stimulated by UV light and Ha-Ras that binds and phosphorylates the c-Jun activation domain. Cell 76: 1025-1037.

Feinstein, S.C., S.L. Dana, L. McConlogue, E.M. Shooter, and P. Coffino. 1985. Nerve growth factor rapidly induces ornithine decarboxylase mRNA in PC12 rat pheochromocytoma cells. Proc. Natl. Acad. Sci. 82: 5761-5765.

Fu, X.-Y. 1992. A transcription factor with $\mathrm{SH} 2$ and $\mathrm{SH} 3$ domains is directly activated by an interferon $\alpha$-induced cytoplasmic protein tyrosine kinase(s). Cell 70: 323-335.

Fu, X.-Y. and J.-J. Zhang. 1993. Transcription factor p91 interacts with the epidermal growth factor receptor and mediates activation of the c-fos gene promoter. Cell 74: 1135-1145.

Ghosh, S. and D. Baltimore. 1990. Activation in vitro of NF-kB by phosphorylation of its inhibitor IкB. Nature 344: 678682

Gille, H., A.D. Sharrocks, and P.E. Shaw. 1992. Phosphorylation of transcription factor $\mathrm{p} 62^{\mathrm{TCF}}$ by MAP kinase stimulates ternary complex formation at c-fos promoter. Nature 358: 414417.

Granelli-Piperno, A., L. Andrus, and R.M. Steinman. 1986. Lymphokine and nonlymphokine mRNA levels in stimulated human $T$ cells: Kinetics, mitogen requirements, and effects of cyclosporin A. J. Exp. Med. 163: 922-937. 
Greenberg, M.E., L.A. Greene, and E.B. Ziff. 1985. Nerve growth factor and epidermal growth factor induce rapid transient changes in proto-oncogene transcription in PC12 cells. I. Biol. Chem. 260: 14101-14110.

Greenberg, M.E. and E.B. Ziff. 1984. Stimulation of 3T3 cells induces transcription of the c-fos proto-oncogene. Nature 311: 433-438.

Harlow, E. and D. Lane. 1988. Antibodies: A laboratory manual. Cold Spring Harbor Laboratory, Cold Spring Harbor, NY.

Hibi, M., A. Lin, T. Smeal, A. Minden, and M. Karin. 1993. Identification of an oncoprotein- and UV-responsive protein kinase that binds and potentiates the c-Jun activation domain. Genes \& Dev. 7: 2135-2148.

Hill, C.S. and R. Treisman. 1995. Transcriptional regulation by extracellular signals: Mechanisms and specificity. Cell 80: 199-211.

Huang, H.-C., R. Sundseth, and U. Hansen. 1990. Transcription factor LSF binds two variant bipartite sites within the SV40 late promoter. Genes \& Dev. 4: 287-298.

Hunter, T. 1995. Protein kinases and phosphatases: The yin and yang of protein phosphorylation and signaling. Cell 80: $225-$ 236.

Hunter, T. and M. Karin. 1992. The regulation of transcription by phosphorylation. Cell 70: 375-387.

Janknecht, R., R.A. Hipskind, T. Houthaeve, A. Nordheim, and H.G. Stunnenberg. 1992. Identification of multiple SRF Nterminal phosphorylation sites affecting DNA binding properties. EMBO \%. 11: 1045-1054.

Jones, K.A., P.A. Luciw, and N. Duchange. 1988. Structural arrangements of transcription control domains within the $5^{\prime}$ untranslated leader regions of the HIV-1 and HIV-2 promoters. Genes \& Dev. 2: 1101-1114.

Kahana, C. and D. Nathans. 1984. Isolation of cloned cDNA encoding mammalian ornithine decarboxylase. Proc. Natl. Acad. Sci. 81: 3645-3649.

Kapiloff, M.S., Y. Farkash, M. Wegner, and M.G. Rosenfeld. 1991. Variable effects of phosphorylation of Pit-1 dictated by the DNA response elements. Science 253: 786-789.

Kato, H., M. Horikoshi, and R.G. Roeder. 1991. Repression of HIV-1 transcription by a cellular protein. Science 251: 14761479 .

Katz, A. and C. Kahana. 1987. Transcriptional activation of mammalian ornithine decarboxylase during stimulated growth. Mol. Cell. Biol. 7: 2641-2643.

Klimczak, L.J., U. Schindler, and A.R. Cashmore. 1992. DNAbinding activity of the Arabidopsis G-box binding factor GBF1 is stimulated by phosphorylation by casein kinase II from broccoli. Plant Cell 4: 87-98.

Lim, L.C., S.L. Swendeman, and M. Sheffery. 1992. Molecular cloning of the $\alpha$-globin transcription factor CP2. Mol. Cell. Biol. 12: 828-835.

Lin, A., J. Frost, T. Deng, T. Smeal, N. Al-Alawi, U. Kikkawa, T. Hunter, D. Brenner, and M. Karin. 1992. Casein kinase II is a negative regulator of $\mathrm{c}$-Jun DNA binding and AP-1 activity. Cell 70: 777-789.

Malim, M.H., R. Fenrick, D.W. Ballard, J. Hauber, E. Böhnlein, and B.R. Cullen. 1989. Functional characterization of a complex protein-DNA-binding domain located within the human immunodeficiency virus type 1 long terminal repeat leader region. J. Virol. 63: 3213-3219.

Manak, J.R. and R. Prywes. 1991. Mutation of serum response factor phosphorylation sites and the mechanism by which its DNA-binding activity is increased by casein kinase II. Mol. Cell. Biol. 11: 3652-3659.

Mar, P.K., A.P. Kumar, D.-C. Kang, B. Zhao, L.A. Martinez, R.L.
Montgomery, L. Anderson, and A.P. Butler. 1995. Characterization of novel phorbol ester- and serum-responsive sequences of the rat ornithine decarboxylase gene promoter. Mol. Carcinogen. 14: 240-250.

Marais, R.M., J.J. Hsuan, C. McGuigan, J. Wynne, and R. Treisman. 1992. Casein kinase II phosphorylation increases the rate of serum response factor-binding site exchange. $E M B O T$. 11: $97-105$

Marais, R., J. Wynne, and R. Treisman. 1993. The SRF accessory protein Elk-1 contains a growth factor-regulated transcriptional activation domain. Cell 73: 381-393.

Minden, A., A. Lin, T. Smeal, B. Dérijard, M. Cobb, R. Davis, and M. Karin. 1994. c-Jun N-terminal phosphorylation correlates with activation of the JNK subgroup but not the ERK subgroup of mitogen-activated protein kinases. Mol. Cell. Biol. 14: 6683-6688.

Moll, T., G. Tebb, U. Surana, H. Robitsch, and K. Nasmyth. 1991. The role of phosphorylation and the CDC28 protein kinase in cell cycle-regulated nuclear import of the S. cerevisiae transcription factor SWI5. Cell 66: 743-758.

Montminy, M. 1993. Trying on a new pair of SH2s. Science 261: 1694-1695.

Olson, E.N. and G. Spizz. 1986. Mitogens and protein synthesis inhibitors induce ornithine decarboxylase gene transcription through separate mechanisms in the $\mathrm{BC}_{3} \mathrm{H} 1$ muscle cell line. Mol. Cell. Biol. 6: 2792-2799.

Pulverer, B.J., J.M. Kyriakis, J. Avruch, E. Nikolakaki, and J.R. Woodgett. 1991. Phosphorylation of c-jun mediated by MAP kinases. Nature 353: 670-674.

Rao, A. 1991. Signaling mechanisms in T cells. Crit. Rev. Immunol. 10: 495-519.

Reed, J.C., J.D. Alpers, P.C. Nowell, and R.G. Hoover. 1986. Sequential expression of protooncogenes during lectinstimulated mitogenesis of normal human lymphocytes. Proc. Natl. Acad. Sci. 83: 3982-3986.

Reed, J.C., J.D. Alpers, P.A. Scherle, R.G. Hoover, P.C. Nowell, and M.B. Prystowsky. 1987. Proto-oncogene expression in cloned T lymphocytes: Mitogens and growth factors induce different patterns of expression. Oncogene 1: 223-228.

Rivera, V.M., C.K. Miranti, R.P. Misra, D.D. Ginty, R.-H. Chen, J. Blenis, and M.E. Greenberg. 1993. A growth factor-induced kinase phosphorylates the serum response factor at a site that regulates its DNA-binding activity. Mol. Cell. Biol. 13: 6260-6273.

Roberts, S.B., N. Segil, and N. Heintz. 1991. Differential phosphorylation of the transcription factor Oct 1 during the cell cycle. Science 253: 1022-1026.

Segil, N., S.B. Roberts, and N. Heintz. 1991. Mitotic phosphorylation of the Oct-1 homeodomain and regulation of Oct-1 DNA binding activity. Science 254: 1814-1816.

Sells, M.A. and J. Chernoff. 1995. Epitope-tag vectors for eukaryotic protein production. Gene 152: 187-189.

Shirodkar, S., M. Ewen, J.A. DeCaprio, J. Morgan, D.M. Livingston, and T. Chittenden. 1992. The transcription factor E2F interacts with the retinoblastoma product and a p107-cyclin A complex in a cell cycle-regulated manner. Cell 68: 157-166.

Shirra, M.K., Q. Zhu, H.-C. Huang, D. Pallas, and U. Hansen. 1994. One exon of the human LSF gene includes conserved regions involved in novel DNA-binding and dimerization motifs. Mol. Cell. Biol. 14: 5076-5087.

Shirra, M.K. 1995. "Characterization of DNA-binding and oligomerization properties of the mammalian transcription factor LSF." Ph.D. thesis, Harvard University, Cambridge, MA.

Shuai, K., G.R. Stark, I.M. Kerr, and J.E. Darnell, Jr. 1993. A single phosphotyrosine residue of Stat91 required for gene activation by interferon- $\gamma$. Science 261: 1744-1746. 
Volker et al.

Su, B., E. Jacinto, M. Hibi, T. Kallunki, M. Karin, and Y. BenNeriah. 1994. JNK is involved in signal integration during costimulation of T lymphocytes. Cell 77: 727-736.

Tanaka, M., R. Gupta, and B.J. Mayer. 1995. Differential inhibition of signaling pathways by dominant-negative $\mathrm{SH} 2 /$ SH3 adapter proteins. Mol. Cell. Biol. 15: 6829-6837.

Uv, A.E., C.R.L. Thompson, and S.J. Bray. 1994. The Drosophila tissue-specific factor grainyhead contains novel DNA-binding and dimerization domains which are conserved in the human protein CP2. Mol. Cell. Biol. 14: 4020-4031.

Vojtek, A.B. and J.A. Cooper. 1995. Rho family members: Activators of MAP kinase cascades. Cell 82: 527-529.

Wen, Z., Z. Zhong, and J.E. Darnell Jr. 1995. Maximal activation of transcription by Stat 1 and $S t a t 3$ requires both tyrosine and serine phosphorylation. Cell 82: 241-250.

Wu, F.K., J.A. Garcia, D. Harrich, and R.B. Gaynor. 1988. Purification of the human immunodeficiency virus type 1 enhancer and TAR binding proteins EBP-1 and UBP-1. EMBO I. 7: 2117-2129.

Yoon, J.-B., G. Li, and R.G. Roeder. 1994. Characterization of a family of related cellular transcription factors which can modulate human immunodeficiency virus type 1 transcription in vitro. Mol. Cell. Biol. 14: 1776-1785. 


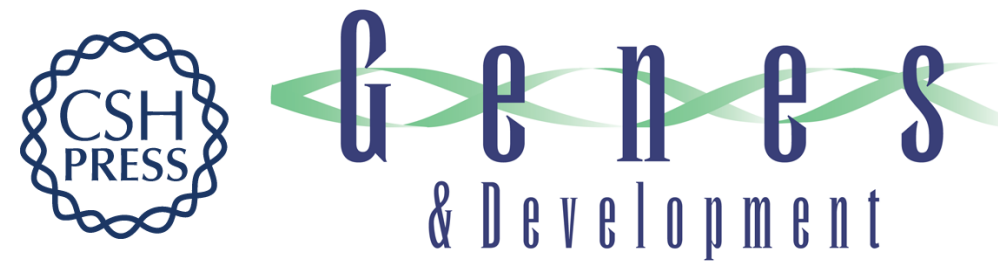

\section{Mitogenic stimulation of resting $T$ cells causes rapid phosphorylation of the transcription factor LSF and increased DNA-binding activity.}

J L Volker, L E Rameh, Q Zhu, et al.

Genes Dev. 1997, 11:

Access the most recent version at doi:10.1101/gad.11.11.1435

References This article cites 63 articles, 34 of which can be accessed free at:

http://genesdev.cshlp.org/content/11/11/1435.full.html\#ref-list-1

License

Email Alerting

Receive free email alerts when new articles cite this article - sign up in the box at the top

Service right corner of the article or click here.

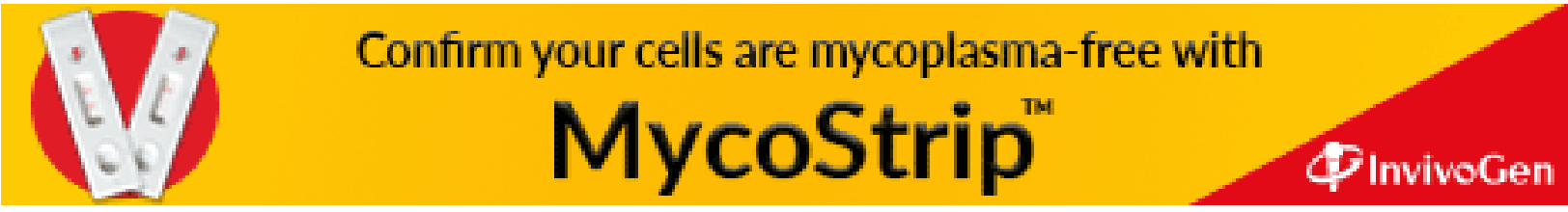

